\title{
New Bisindole Alkaloids Isolated from Myxomycetes Arcyria cinerea and Lycogala epidendrum
}

\author{
Kazuaki Kamata, ${ }^{a}$ Makiko KiYota, ${ }^{a}$ Ayano NaOe, ${ }^{a}$ Satomi Nakatani, ${ }^{a}$ Yukinori Yamamoto, ${ }^{b}$ \\ Masahiko Hayashi, ${ }^{c}$ Kanki KomiYama, ${ }^{c}$ Takao YAMORI ${ }^{d}$ and Masami IshiBashi ${ }^{*}, a$ \\ ${ }^{a}$ Graduate School of Pharmaceutical Sciences, Chiba University; 1-33 Yayoi-cho, Inage-ku, Chiba 263-8522, Japan: \\ ${ }^{b}$ 1010-53 Ohtsu-ko, Kochi 781-5102, Japan: ${ }^{c}$ The Kitasato Institute; 5-9-1 Shirokane, Minato-ku, Tokyo 108-8642, \\ Japan: and ${ }^{d}$ Cancer Chemotherapy Center, Japanese Foundation for Cancer Research; 3-10-6 Ariake, Koutou-ku, Tokyo \\ 135-8550, Japan. Received February 10, 2005; accepted February 28, 2005; published online March 15, 2005
}

Two new bisindole alkaloids, named cinereapyrrole A (1) and B (2), were isolated from wild fruit bodies of Arcyria cinerea and three new bisindole alkaloids (3-5) were isolated from wild fruit bodies of Lycogala epidendrum. Seven known bisindoles (6-12) were concomitantly obtained from them. The structures of the new compounds were elucidated by spectral data. Among these bisindole alkaloids, compound 12 showed cytotoxicity against cultured tumor cell lines.

Key words myxomycetes; Arcyria cinerea; Lycogala epidendrum; bisindole; cytotoxicity

The myxomycetes (true slime molds) are an unusual group of primitive organisms that may be assigned to one of the lowest classes of eukaryotes. ${ }^{1)}$ During our studies on search for bioactive natural products from myxomycetes, ${ }^{2-4)}$ we recently investigated a field-collected sample of fruit bodies of Arcyria cinerea and Lycogala epidendrum collected at Kochi prefecture. Here we describe isolation and structure elucidation of new bisindole alkaloids (1-5) along with seven known bisindoles (6-12), and their cytotoxic activity. Particularly, compound $\mathbf{1 2}$ was found to be cytotoxic against a panel of 39 human cancer cell lines.

\section{Results and Discussion}

The wild fruit bodies of Arcyria cinerea, collected in Kochi Prefecture, Japan, were extracted with $90 \% \mathrm{MeOH}$ and $90 \%$ acetone. The combined extracts were separated by chromatographies on silica gel, ODS, and Sephadex LH-20 to give two new bisindole alkaloids, named cinereapyrrole A (1) and B (2), together with a known compound, arcyriarubin A (6), which was previously isolated from Arcyria denudata, ${ }^{5)}$ and Lycogala epedindrum. ${ }^{6}$

Cinereapyrrole A (1) was shown to have the molecular formula $\mathrm{C}_{22} \mathrm{H}_{17} \mathrm{~N}_{3} \mathrm{O}_{4}$ by the HR-FAB-MS data $(\mathrm{m} / \mathrm{z} 387.1208$, $\left.\left[\mathrm{M}^{+}\right], \Delta-1.1 \mathrm{mmu}\right)$. The UV spectrum of $\mathbf{1}$ showed absorption maximum at $283 \mathrm{~nm}$, indicating the presence of conjugated system(s), while the IR absorption bands observed at 3396 and $1695 \mathrm{~cm}^{-1}$ implied the presence of hydroxy and conjugated carbonyl groups. The ${ }^{1} \mathrm{H}-\mathrm{NMR}$ spectrum of 1 in $\mathrm{CD}_{3} \mathrm{OD}$ (Table 1) showed ten signals for nine aromatic protons and one methoxy group. The analysis of the ${ }^{13} \mathrm{C}$-NMR (Table 2) and HMQC spectra of $\mathbf{1}$ clarified the presence of twenty two carbons including nine $s p^{2}$ methines, eleven $s p^{2}$ quaternary carbons, one methoxy $\left(\delta_{\mathrm{C}}\right.$ 51.3), and one carboxy or carboxy ester carbon $\left(\delta_{\mathrm{C}} 163.6\right)$. By analysis of the ${ }^{1} \mathrm{H}-{ }^{1} \mathrm{H}$ COSY and HMBC spectra of compound 1 suggested the presence of two sets of 5-hydroxyindole moieties by observation of the following cross peaks $\left[{ }^{1} \mathrm{H}-{ }^{1} \mathrm{H}\right.$ COSY: H-6/H-7 and H-6'/H-7'; HMBC: H-2/C-3, H2/C-3a, H-2/C-7a, H-4/C-3, H-4/C-5, H-4/C-7a, H-6/C-7a, H-7/C-3a, H-7/C-5, H-2'/C-3', H-2'/C-3a', H-2'/C-7a', H- $4^{\prime} / \mathrm{C}-7 \mathrm{a}^{\prime}, \mathrm{H}-6^{\prime} / \mathrm{C}-7 \mathrm{a}^{\prime}, \mathrm{H}-7^{\prime} / \mathrm{C}-3 \mathrm{a}^{\prime}$, and $\left.\mathrm{H}-7^{\prime} / \mathrm{C}-5^{\prime}\right]$. The ${ }^{13} \mathrm{C}-$ NMR chemical shifts of C-5 $\left(\delta_{\mathrm{C}} 151.0\right)$ and C-5 $\left(\delta_{\mathrm{C}} 151.4\right)$ suggested these carbons bore hydroxy groups. These NMR data were reminiscent of those of lycogarubin A (13), previously isolated from Lycogala epidendrum. ${ }^{7}$ Lycogarubin A (13) was an symmetrical compound with one set of NMR signals, while NMR data of $\mathbf{1}$ implied that compound $\mathbf{1}$ was an unsymmetrical molecule. Another difference was the observation of an additional $s p^{2}$ proton observed at $\delta_{\mathrm{H}} 7.29$ $(1 \mathrm{H}, \mathrm{s})$ in the ${ }^{1} \mathrm{H}-\mathrm{NMR}$ of $\mathbf{1}$, which showed HMBC correlations to $\mathrm{C}-8, \mathrm{C}-8^{\prime}$ and $\mathrm{C}-9$ '. Thus, this additional hydrogen was placed on the C-9 position, while a methoxycarbonyl group was inferred to be attached on the C-9' position as in case of lycogarubin A (13); the methoxy protons at $\delta_{\mathrm{H}} 3.65$ $(3 \mathrm{H}, \mathrm{s})$ showed an HMBC correlation to the ester carbonyl carbon $\left(\delta_{\mathrm{C}}\right.$ 163.6). An NOE correlation observed between H-9 and H-4 further confirmed the presence of a hydrogen atom at the C-9 position. The structure of cinereapyrrole A was therefore concluded as $\mathbf{1}$.

Cinereapyrrole B (2) had a molecular formula of $\mathrm{C}_{22} \mathrm{H}_{17} \mathrm{~N}_{3} \mathrm{O}_{3}$ as shown by the HR-FAB-MS data $(\mathrm{m} / \mathrm{z}$ 371.1278, [M $\left.\left.{ }^{+}\right], \Delta+0.8 \mathrm{mmu}\right)$. The UV and IR spectral data
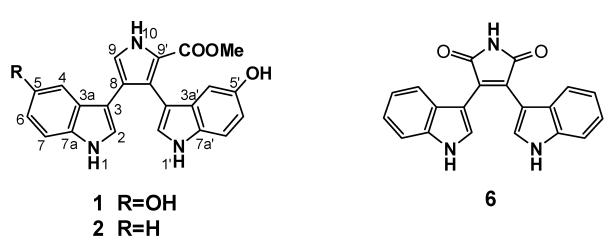

6

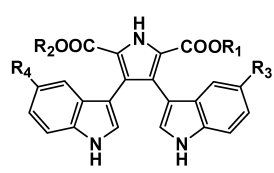

$3 \mathrm{R}_{1}=\mathrm{Me}, \mathrm{R}_{2}=\mathrm{H}, \mathrm{R}_{3}=\mathrm{R}_{4}=\mathrm{H}$

$4 \mathrm{R}_{1}=\mathrm{Me}, \mathrm{R}_{2}=\mathrm{H}, \mathrm{R}_{3}=\mathrm{OH}, \mathrm{R}_{4}=\mathrm{H}$

$5 \quad \mathrm{R}_{1}=\mathrm{Me}, \mathrm{R}_{2}=\mathrm{H}, \mathrm{R}_{3}=\mathrm{H}, \mathrm{R}_{4}=\mathrm{OH}$

$7 \quad R_{1}=R_{2}=M e, R_{3}=R_{4}=H$

$9 \quad \mathrm{R}_{1}=\mathrm{R}_{2}=\mathrm{Me}, \mathrm{R}_{3}=\mathrm{OH}, \mathrm{R}_{4}=\mathrm{H}$

$11 \mathrm{R}_{1}=\mathrm{R}_{2}=\mathrm{H}, \mathrm{R}_{3}=\mathrm{R}_{4}=\mathrm{H}$

$13 R_{1}=R_{2}=M e, R_{3}=R_{4}=O H$ 
Table 1. ${ }^{1} \mathrm{H}$-NMR Spectral Data of Compounds $\mathbf{1}-\mathbf{5}$ and $\mathbf{9}$

\begin{tabular}{|c|c|c|c|c|c|c|}
\hline Position & $1\left(\mathrm{CD}_{3} \mathrm{OD}\right)$ & $2\left(\mathrm{CD}_{3} \mathrm{COCD}_{3}\right)$ & $3\left(\mathrm{CD}_{3} \mathrm{COCD}_{3}\right)$ & $4\left(\mathrm{CD}_{3} \mathrm{COCD}_{3}\right)$ & $5\left(\mathrm{CD}_{3} \mathrm{COCD}_{3}\right)$ & $9\left(\mathrm{CD}_{3} \mathrm{COCD}_{3}\right)$ \\
\hline 1 & & 9.86 br s & 9.99 br s & 10 br s & 10 br s & 10.00 br s \\
\hline 2 & $7.01 \mathrm{~s}$ & $6.76 \mathrm{~d} 2.6$ & $7.03 \mathrm{~s}$ & $7.11 \mathrm{~d} 2.4$ & $7.07 \mathrm{~d} 2.4$ & $7.11 \mathrm{~d} 2.4$ \\
\hline \multicolumn{7}{|l|}{3} \\
\hline \multicolumn{7}{|l|}{$3 a$} \\
\hline 4 & $7.01 \mathrm{~d} 1.9$ & $7.64 \mathrm{~d} 8.1$ & $7.19^{a)} \mathrm{d} 7.5$ & $7.16 \mathrm{~d} 7.7$ & $7.27 \mathrm{~d} 7.9$ & $7.16 \mathrm{~d} 7.9$ \\
\hline 5 & & 6.95 ddd $8.1,7.0,1.2$ & $6.79^{b)} \mathrm{t} 7.5$ & $6.78 \mathrm{t} 7.7$ & 6.79 t 7.9 & $6.81 \mathrm{td} 7.9,0.9$ \\
\hline 6 & 6.60 dd $8.4,1.9$ & 7.04 ddd $8.1,7.0,1.2$ & $6.94^{c)} \mathrm{t} 7.5$ & $6.94 \mathrm{t} 7.7$ & $6.95 \mathrm{td} 7.9,1.2$ & $6.97 \mathrm{td} 7.9,1.2$ \\
\hline 7 & 7.16 dd $8.4,0.6$ & $7.31 \mathrm{dt} 8.1,1.2$ & $7.25 \mathrm{dd} 7.5,1.0$ & $7.26 \mathrm{~d} 7.7$ & $7.27 \mathrm{~d} 7.9$ & 7.29 dd $7.9,0.9$ \\
\hline \multicolumn{7}{|l|}{$7 \mathrm{a}$} \\
\hline \multicolumn{7}{|l|}{8} \\
\hline 9 & $7.29 \mathrm{~s}$ & 7.44 d 3.6 & & & & \\
\hline 10 & & 10.9 brs & $10.90 \mathrm{br} \mathrm{s}$ & $10.80 \mathrm{brs}$ & 10.8 br s & 10.99 br s \\
\hline $1^{\prime}$ & & 9.89 br s & 9.99 br s & 9.71 br s & 9.72 br s & 9.70 br s \\
\hline $2^{\prime}$ & $6.54 \mathrm{~s}$ & $7.10 \mathrm{~d} 2.6$ & $7.06 \mathrm{~s}$ & $6.87 \mathrm{~d} 2.8$ & $6.91 \mathrm{~d} 2.4$ & $6.90 \mathrm{~d} 2.4$ \\
\hline \multicolumn{7}{|l|}{$3^{\prime}$} \\
\hline \multicolumn{7}{|l|}{$3 a^{\prime}$} \\
\hline $4^{\prime}$ & 6.56 dd $2.6,0.6$ & $6.62 \mathrm{~s}$ & $7.21^{a)} \mathrm{d} 7.3$ & $6.69 \mathrm{~d} 2.1$ & $6.71 \mathrm{~d} 2.2$ & $6.71 \mathrm{~d} 1.9$ \\
\hline $5^{\prime}$ & & & $6.81^{b)} \mathrm{t} 7.3$ & & & \\
\hline $6^{\prime}$ & $6.61 \mathrm{dd} 8.7,2.6$ & 6.63 dd $8.2,2.3$ & $6.96^{c)}$ t 7.3 & $6.59 \mathrm{dd} 8.5,2.1$ & $6.58 \mathrm{dd} 8.4,2.2$ & $6.63 \mathrm{dd} 8.3,1.9$ \\
\hline $7^{\prime}$ & $7.08 \mathrm{~d} 8.7$ & $7.19 \mathrm{~d} 8.2$ & $7.25 \mathrm{dd} 7.3,1.0$ & $7.08 \mathrm{~d} 8.5$ & $7.07 \mathrm{~d} 8.4$ & $7.10 \mathrm{~d} 8.3$ \\
\hline \multicolumn{7}{|l|}{$7 a^{\prime}$} \\
\hline \multicolumn{7}{|l|}{$8^{\prime}$} \\
\hline \multicolumn{7}{|l|}{$9^{\prime}$} \\
\hline $\mathrm{OMe}$ & 3.65 & $3.57 \mathrm{~s}$ & $3.62 \mathrm{~s}$ & $3.63 \mathrm{~s}$ & $3.62 \mathrm{~s}$ & 3.63 \\
\hline $5^{\prime}-\mathrm{OH}$ & & 7.35 br s & & 7.40 br s & 7.40 br s & 7.42 \\
\hline
\end{tabular}

$a-c)$ Signals may be reversed.

were paralles to those of $\mathbf{1}$, and the ${ }^{1} \mathrm{H}$ - and ${ }^{13} \mathrm{C}$-NMR data (Tables 1,2 ) were also similar to those of compound $\mathbf{1}$. The difference was observed in the ${ }^{1} \mathrm{H}-\mathrm{NMR}$ spectrum of $\mathbf{2}$, showing four consecutive aromatic proton signals $\left[\delta_{\mathrm{H}} 7.64\right.$ (H-4), $6.95(\mathrm{H}-5), 7.04(\mathrm{H}-6)$, and $7.31(\mathrm{H}-7)]$, which was supported by the ${ }^{1} \mathrm{H}-{ }^{1} \mathrm{H}$ COSY spectrum of 2 [cross peaks: $\mathrm{H}-4 / \mathrm{H}-5, \mathrm{H}-5 / \mathrm{H}-6$, and $\mathrm{H}-6 / \mathrm{H}-7]$. These aromatic proton signals were assigned to a part of an indole nucleus without any substituents on the benzene ring part, while the ${ }^{1} \mathrm{H}-\mathrm{NMR}$ spectrum of 2 also showed signals assignable to 5-hydroxyindole moiety $\left[\delta_{\mathrm{H}} 6.62\left(\mathrm{H}-4^{\prime}\right), 6.63\left(\mathrm{H}-6^{\prime}\right)\right.$, and $\left.7.19\left(\mathrm{H}-7^{\prime}\right)\right]$, as possessed by compound $\mathbf{1}$, which was confirmed by the HMBC spectrum of 2 in acetone- $d_{6}$ observed for $\mathrm{H}-2^{\prime} / \mathrm{C}-3 \mathrm{a}^{\prime}$, $\mathrm{H}-2^{\prime} / \mathrm{C}-7 \mathrm{a}^{\prime}, \mathrm{H}-4^{\prime} / \mathrm{C}-3^{\prime}, \mathrm{H}-4^{\prime} / \mathrm{C}-6^{\prime}, \mathrm{H}-6^{\prime} / \mathrm{C}-4^{\prime}, \mathrm{H}-6^{\prime} / \mathrm{C}-7 \mathrm{a}^{\prime}, \mathrm{H}-$ $7^{\prime} / \mathrm{C}-5^{\prime}, \mathrm{H}-7^{\prime} / \mathrm{C}-3 \mathrm{a}^{\prime}, \mathrm{OH}-5^{\prime} / \mathrm{C}-4^{\prime}, \mathrm{OH}-5^{\prime} / \mathrm{C}-5^{\prime}$, and $\mathrm{OH}-5^{\prime} / \mathrm{C}-$ $6^{\prime}$. Thus, compound 2 was suggested to possess one indole and one 5-hydroxyindole moieties. As in case of compound 1, compound 2 bore a hydrogen atom on C-9 $\left(\delta_{\mathrm{H}} 7.44, \mathrm{H}-9\right)$, which was indicated by the HMBC correlations observed for $\mathrm{H}-9 / \mathrm{C}-8, \mathrm{H}-9 / \mathrm{C}-9$, and $\mathrm{H}-9 / \mathrm{C}-9^{\prime}$ and the ${ }^{1} \mathrm{H}-{ }^{1} \mathrm{H}$ COSY cross peak between $\mathrm{H}-9$ and NH-10 in acetone- $d_{6}$ solution. An NOE was observed between H-9 $\left(\delta_{\mathrm{H}} 7.44\right)$ and H-4 $\left(\delta_{\mathrm{H}}\right.$ 7.64), thus suggesting that the indole ring without $5-\mathrm{OH}$ group was attached on the adjacent position (C-8) to H-9 and the 5-hydroxyindole ring therefore present at the neighboring position $\left(\mathrm{C}-8^{\prime}\right)$ to the methoxycarobonyl group. Thus, structure of cinereapyrrole B was revealed as 2 , which corresponded to cinereapyrrole A (1) without 5-hydroxy group, and also corresponded to lycogarubin B $(9)^{7)}$ without 9methoxycarbonyl group.

The fruit bodies of Lycogala epidendrum, collected in Kochi Prefecture, Japan, were also extracted with $90 \%$ $\mathrm{MeOH}$ and $90 \%$ acetone. The combined extracts were partitioned between EtOAc and water, and the EtOAc layer was
Table 2. ${ }^{13} \mathrm{C}-\mathrm{NMR}$ Spectral Data of Compounds $\mathbf{1}-\mathbf{5}$ and $\mathbf{9}$

\begin{tabular}{|c|c|c|c|c|c|c|}
\hline Position & $\mathbf{1}^{a)}$ & $\mathbf{2}^{b)}$ & $3^{b)}$ & $4^{b)}$ & $\mathbf{5}^{b)}$ & $\mathbf{9}^{b)}$ \\
\hline \multicolumn{7}{|l|}{1} \\
\hline 2 & 126.5 & 126.5 & 125.6 & 126.0 & 125.9 & 126.2 \\
\hline 3 & 110.2 & 110.8 & 109.3 & 109.4 & 109.4 & 109.2 \\
\hline $3 a$ & 129.9 & 129.9 & 128.8 & 129.1 & 128.9 & 128.8 \\
\hline 4 & 104.7 & 120.4 & 120.6 & 120.7 & 120.7 & 120.5 \\
\hline 5 & 151.0 & 119.7 & 119.3 & 119.3 & 119.3 & 119.3 \\
\hline 6 & 112.0 & 121.8 & 121.5 & 121.5 & 121.5 & 121.5 \\
\hline 7 & 112.3 & 111.8 & 111.8 & 111.8 & 111.9 & 111.8 \\
\hline $7 \mathrm{a}$ & 132.8 & 137.1 & 136.8 & 136.9 & 136.9 & 136.9 \\
\hline 8 & $124.8^{c)}$ & $123.1^{d)}$ & $125.9^{e)}$ & $125.8^{f)}$ & $126.0^{g)}$ & 125.9 \\
\hline 9 & 121.9 & 121.3 & $123.3^{e)}$ & $123.5^{f)}$ & $123.4^{g)}$ & 123.6 \\
\hline \multicolumn{7}{|l|}{10} \\
\hline \multicolumn{7}{|l|}{$1^{\prime}$} \\
\hline $2^{\prime}$ & 124.8 & 123.5 & 125.7 & 126.2 & 126.3 & 126.2 \\
\hline $3^{\prime}$ & 110.1 & 109.9 & 109.3 & 108.8 & 108.8 & 108.6 \\
\hline $3 a^{\prime}$ & 128.7 & 129.8 & 129.0 & 129.9 & 130.2 & 129.9 \\
\hline $4^{\prime}$ & 105.5 & 105.1 & 120.6 & 104.8 & 104.9 & 104.7 \\
\hline $5^{\prime}$ & 151.4 & 151.5 & 119.3 & 151.5 & 151.6 & 151.5 \\
\hline $6^{\prime}$ & 111.9 & 112.0 & 121.5 & 111.8 & 111.8 & 111.8 \\
\hline $7^{\prime}$ & 112.5 & 112.2 & 111.8 & 112.1 & 112.1 & 112.1 \\
\hline $7 a^{\prime}$ & 132.6 & 132.0 & 136.8 & 131.7 & 131.7 & 131.6 \\
\hline $8^{\prime}$ & $122.3^{c)}$ & $121.6^{d)}$ & $126.1^{e)}$ & $126.4^{f f}$ & $126.2^{g)}$ & 125.9 \\
\hline $9^{\prime}$ & $120.7^{c)}$ & $121.0^{d)}$ & $124.0^{e)}$ & $124.1^{f f}$ & $124.2^{g)}$ & 123.6 \\
\hline COOMe & 163.6 & 162.0 & 161.9 & 161.5 & 161.5 & 161.5 \\
\hline $\mathrm{COOH}$ & - & - & 161.5 & 161.8 & 161.8 & - \\
\hline $\mathrm{OMe}$ & 51.3 & 50.8 & 51.5 & 51.5 & 51.4 & 51.5 \\
\hline
\end{tabular}

a) In $\mathrm{CD}_{3} \mathrm{OD} . \quad$ b) In $\mathrm{CD}_{3} \mathrm{COCD}_{3} . \quad c-g$ ) Signals may be reversed.

then subjected to chromatographies on silica gel, ODS, and Sephadex LH-20 to give three new compounds $\mathbf{3}-\mathbf{5}$ as well as six known bisindoles, which were identified as lycogarubin C (7), ${ }^{7}$ arcyriaflavin A (8), ${ }^{6}$ lycogarubin B (9), ${ }^{7}$ staurosporinone (10) ${ }^{8)}$ lycogaric acid A (11) $\left.{ }^{6}\right)$ and arcyriaflavin $\mathrm{B}(\mathbf{1 2})^{5)}$ on the basis of comparison of the spectral data. 
The molecular formula of compound $\mathbf{3}$ was revealed as $\mathrm{C}_{23} \mathrm{H}_{17} \mathrm{~N}_{3} \mathrm{O}_{4}$ by the HR-FAB-MS data $\left(m / z\right.$ 399.1184, $[\mathrm{M}]^{+}$, $\Delta-3.5 \mathrm{mmu})$. The ${ }^{1} \mathrm{H}-\mathrm{NMR}$ spectral data of 3 were similar to those of lycogarubin $\mathrm{C}$ (7), but 3 had only one methoxy group, while lycogarubin $\mathrm{C}(7)$ had two. Lycogarubin $\mathrm{C}$ (7) was a symmetrical bisindole with two methyl ester groups, whereas the ${ }^{1} \mathrm{H}$ - and ${ }^{13} \mathrm{C}-\mathrm{NMR}$ data of 3 (Tables 1,2 ) showed that $\mathbf{3}$ was unsymmetrical. Thus, compound $\mathbf{3}$ was deduced to have one carboxylic acid and one methyl ester, corresponding to monodemethyl derivative of lycogarubin $\mathrm{C}$ (7). Compounds 4 and 5 had the same molecular formula of $\mathrm{C}_{23} \mathrm{H}_{17} \mathrm{~N}_{3} \mathrm{O}_{5}$ as revealed by the HR-FAB-MS data (4: $m / z$ 415.1179, $[\mathrm{M}]^{+}, \Delta+1.1 \mathrm{mmu} ; 5: \mathrm{m} / z$ 415.1179, $[\mathrm{M}]^{+}, \Delta$ $+1.1 \mathrm{mmu}$ ). The ${ }^{1} \mathrm{H}$ - and ${ }^{13} \mathrm{C}$-NMR spectra of 4 and 5 (Tables 1,2$)$ were similar to each other and both of them also resembled those of lycogarubin B (9) (Tables 1,2$),{ }^{7}$ which was an asymmetric molecule with one indole and one 5-hydorxyindole moieties with two methoxycarbonyl groups at $\mathrm{C}-9$ and $\mathrm{C}-9$ ' positions. The ${ }^{1} \mathrm{H}-$ and ${ }^{13} \mathrm{C}-\mathrm{NMR}$ data showed that both compounds $\mathbf{4}$ and $\mathbf{5}$ had only one methoxy groups. This fact as well as interpretation of the ${ }^{1} \mathrm{H}-{ }^{1} \mathrm{H}$ COSY and HMBC spectral data suggested that compounds $\mathbf{4}$ and $\mathbf{5}$ were monodemethyl derivatives of lycogarubin B (9). The NOE experiment using compound $\mathbf{4}$ showed an NOE correlation observed between the methoxy protons and $\mathrm{H}-4$ ', which was on the 5-hydroxyindole group. This result suggested that compound 4 had the 5-hydroxyindole on the adjacent position $\left(\mathrm{C}-8^{\prime}\right)$ to the methoxycarbonyl group on $\mathrm{C}-9^{\prime}$ while compound $\mathbf{5}$ was an isomer of $\mathbf{4}$ possessing the indole group on $\mathrm{C}-8^{\prime}$.

Compounds 8, 10, and 12, which had a $\mathrm{C}-\mathrm{C}$ bond connection between C-2 and C-2' positions, showed cytotoxic activity against $\mathrm{HeLa}$ cells with $\mathrm{IC}_{50}$ values of 47.6, 8.9, and $4.4 \mu \mathrm{g} / \mathrm{ml}$, respectively, while compounds $3,7,9$ and 11 without $\mathrm{C}-2 / \mathrm{C}-2^{\prime}$ bond were almost inactive with $\mathrm{IC}_{50}$ values of 93.3, 24.0, >100, >100, respectively. Arcyriaflavin B (12) showed cytotoxicity ( $\mathrm{IC}_{50}$ value, $2.28 \mu \mathrm{g} / \mathrm{ml}$ ) against vincristine (VCR)-resistant KB cells, but didn't show the reversal effect of VCR resistance. Furthermore, arcyriaflavin B (12) was evaluated in the Japanese Foundation for Cancer Research 39 cell line panel assay. ${ }^{9)}$ Although compound 12 showed low differential cellular sensitivities, NCI-H522 and DMS273 lung cells, BSY-1 breast cancer cells, and SF-539 CNS cancer cells were relatively sensitive to $\mathbf{1 2}$ with $\mathrm{LC}_{50}$ values of $6.2,6.7,6.8$, and $6.9 \mu \mathrm{M}$, respectively, while SNB78 CNS cancer cells, HT-29 colon cells, NCI-H226 lung cells, and MKN28 stomach cells were relatively resistant with $\mathrm{LC}_{50}$ values of $51,55,58$, and $55 \mu \mathrm{M}$, respectively.

\section{Experimental}

General Procedures UV spectra were obtained on a Shimadzu UV mini-1240 spectrometer. IR spectra were measured from samples on a Hitachi 260-10 infrared spectrophotometer. NMR spectra were recorded on JEOL JNM ecp600 spectrometers. HR-FAB-MS were acquired on a JMS HX-110 mass spectrometer.

Organism The fruit bodies of Arcyria cinerea were collected in Kochi Prefecture, Japan, in January 2003, and a voucher specimen (\#24816 and 24861 ) is maintained by Y. Y. (Ohtsu-ko, Kochi). The fruit bodies of Lycogala epidendrum were also collected in Kochi Prefecture, Japan, in January 2002. A voucher specimen is maintained by Y. Y. (Ohtsu-ko, Kochi).

Extraction and Isolation The air-dried fruit bodies of Arcyria cinerea $(2.9 \mathrm{~g})$ were extracted with $90 \% \mathrm{MeOH}(150 \mathrm{ml} \times 2)$ and $90 \%$ acetone $(150 \mathrm{ml} \times 1)$. A portion $(191 \mathrm{mg})$ of the combined extract $(200 \mathrm{mg})$ was subjected to silica gel column chromatography (column A; $17 \times 210 \mathrm{~mm}$ ) eluted with $20-100 \%$ EtOAc in hexane. A fraction $(8.7 \mathrm{mg})$ of column A eluted with $80 \%$ EtOAc in hexane was then separated by ODS column chromatography (column $\mathrm{B} ; 12 \times 190 \mathrm{~mm}$ ) eluted with $40-100 \% \mathrm{MeOH}$ in water. A fraction $(5.0 \mathrm{mg}$ ) of column B eluted with $40 \% \mathrm{MeOH}$ in water was further purified by sephadex LH-20 column $(10 \times 550 \mathrm{~mm})$ eluted with $\mathrm{MeOH}$ and HPLC on ODS (Develosil ODS-UG-5, $10 \times 250 \mathrm{~mm}$; eluent, $60 \% \mathrm{MeOH}$, flow rate, $1.8 \mathrm{ml} / \mathrm{min}$; detection $\mathrm{UV}$ at $254 \mathrm{~nm})$ to give cinereapyrrole A (1, $2.0 \mathrm{mg})$. A fraction $(2.7 \mathrm{mg})$ of column B eluted with $50 \% \mathrm{MeOH}$ in water was further purified by Sephadex LH-20 column $(10 \times 550 \mathrm{~mm})$ eluted with $\mathrm{MeOH}$ to give cinereapyrrole B $(2,0.8 \mathrm{mg})$. A fraction $(2.8 \mathrm{mg})$ of column A eluted with $50 \%$ EtOAc in hexane was applied on a silica gel column $(8 \times 210 \mathrm{~mm})$ eluted with $0-2 \% \mathrm{MeOH}$ in $\mathrm{CHCl}_{3}$ to give arcyriarubin $\mathrm{A} \mathrm{(6}$, $0.6 \mathrm{mg})$. A fraction $(110 \mathrm{mg})$ of column A eluted with $\mathrm{MeOH}$ was subjected to silica gel column (column C; $15 \times 250 \mathrm{~mm}$ ) eluted with $20-100 \%$ acetone in $\mathrm{CHCl}_{3}$. A fraction $(5.0 \mathrm{mg})$ of column $\mathrm{C}$ eluted with $80-100 \%$ acetone in $\mathrm{CHCl}_{3}$ was further purified by Sephadex LH-20 column $(10 \times 550 \mathrm{~mm})$ eluted with $\mathrm{MeOH}$ to give $3(1.6 \mathrm{mg})$.

The air-dried fruit bodies of Lycogala epidendrum $(35.3 \mathrm{~g})$ were extracted with $90 \% \mathrm{MeOH}(500 \mathrm{ml} \times 2)$ and $90 \%$ acetone $(500 \mathrm{ml} \times 1)$. The combined $\mathrm{MeOH}$ and acetone extract $(6.66 \mathrm{~g})$ was dissolved in 55\% EtOAc in water $(220 \mathrm{ml})$, and then partitioned between EtOAc $(150 \mathrm{ml} \times 3)$ and distilled water $(100 \mathrm{ml})$. The EtOAc-soluble fraction was evaporated under reduce pressure to give a residure $(3.23 \mathrm{~g})$, which was subjected to silica gel column chromatography (column $\mathrm{D} ; 35 \times 300 \mathrm{~mm}$ ) eluted with $0-100 \% \mathrm{MeOH}$ in $\mathrm{CHCl}_{3}$. A fraction $(1.3 \mathrm{~g}$ ) of column D eluted with $5-20 \% \mathrm{MeOH}$ in $\mathrm{CHCl}_{3}$ was further separated on Sephadex LH-20 column (column E; $25 \times 490 \mathrm{~mm})$ eluted with $\mathrm{CHCl}_{3} / \mathrm{MeOH}(1: 1)$. The fraction $(201 \mathrm{mg})$ of column E was subjected to silica gel column (column F; $15 \times 300 \mathrm{~mm}$ ) eluted with $5-100 \%$ acetone in $\mathrm{CHCl}_{3}$, followed by purification with ODS column chromatography $(15 \times 260 \mathrm{~mm})$ eluting with $20-100 \%$ acetone in water to give compound $3(24.2 \mathrm{mg})$. The fraction $(74 \mathrm{mg})$ of column $\mathrm{F}$ eluted with $20 \%$ acetone in $\mathrm{CHCl}_{3}$ was also purified by ODS column chromatography $(12 \times 310 \mathrm{~mm})$ eluting with $50 \%$ acetone in water to give compounds $9(39.5 \mathrm{mg})$ and $10(10.5 \mathrm{mg})$. The fraction $(601 \mathrm{mg})$ of column D eluted with $5 \% \mathrm{MeOH}$ in $\mathrm{CHCl}_{3}$ was further separated on Sephadex LH-20 column $(25 \times 490 \mathrm{~mm})$ eluted with $\mathrm{CHCl}_{3} / \mathrm{MeOH}(3: 4)$ to give compounds 7 $(52.0 \mathrm{mg})$ and $8(1.0 \mathrm{mg})$. A fraction $(574 \mathrm{mg})$ of column D eluted with 20 $50 \% \mathrm{MeOH}$ in $\mathrm{CHCl}_{3}$ was separated on ODS column (column G; $29 \times 290 \mathrm{~mm}$ ) eluted with $33-100 \% \mathrm{MeOH}$ in water to give compound 11 $(78.0 \mathrm{mg})$. A fraction $(85 \mathrm{mg})$ of column G eluted with $50 \% \mathrm{MeOH}$ in water was separated on Sephadex LH-20 column $(12 \times 490 \mathrm{~mm})$ eluted with $\mathrm{MeOH}$, and applied on a silica gel column $\left(10 \times 200 \mathrm{~mm}, \mathrm{CHCl}_{3} / \mathrm{MeOH} /\right.$ $\left.\mathrm{H}_{2} \mathrm{O}, 95: 5: 0.3-1: 1: 0.3\right)$ to give a $6: 4$ mixture $(8.4 \mathrm{mg})$ of compounds 4 and 5. Finaly, this mixture was purified by HPLC on ODS (Develosil ODSUG-5, $10 \times 250 \mathrm{~mm}$; eluent, $30 \% \mathrm{CH}_{3} \mathrm{CN}$, flow rate, $1.8 \mathrm{ml} / \mathrm{min}$; detection $\mathrm{UV}$ at $254 \mathrm{~nm})$ to give compound $4\left(2.7 \mathrm{mg}, t_{\mathrm{R}} 19 \mathrm{~min}\right)$ and $5\left(2.0 \mathrm{mg}, t_{\mathrm{R}}\right.$ $22 \mathrm{~min})$. A fraction $(24 \mathrm{mg})$ of column $\mathrm{G}$ eluted with $70 \% \mathrm{MeOH}$ in water was further separated on silica gel column $(8 \times 140 \mathrm{~mm})$ eluted with $17-$ $100 \%$ acetone in $\mathrm{CHCl}_{3}$ to give compound $\mathbf{1 2}(6.1 \mathrm{mg})$.

Cinereapyrrole A (1): Dark brown amorphous powder; UV $\lambda_{\max }(\mathrm{MeOH})$ 283 ( $\varepsilon$ 11000); IR (film) $v_{\max } 3396,1695,1630,1583$ and $1377 \mathrm{~cm}^{-1} ;{ }^{1} \mathrm{H}-$ and ${ }^{13} \mathrm{C}$-NMR (Tables 1, 2); FAB-MS $m / z 387\left(\mathrm{M}^{+}\right)$; HR-FAB-MS $\mathrm{m} / \mathrm{z}$ 387.1208 [Calcd for $\mathrm{C}_{22} \mathrm{H}_{17} \mathrm{~N}_{3} \mathrm{O}_{4},\left(\mathrm{M}^{+}\right)$387.1219].

Cinereapyrrole B (2): Dark brown amorphous powder; UV $\lambda_{\max }(\mathrm{MeOH})$ 286 ( $\varepsilon 14000)$ and 230 ( $\varepsilon$ 36000); IR (film) $v_{\max } 3400,1696,1454$ and $1377 \mathrm{~cm}^{-1}$; ${ }^{1} \mathrm{H}$ - and ${ }^{13} \mathrm{C}-\mathrm{NMR}$ (Tables 1,2$)$; FAB-MS $m / z 371\left(\mathrm{M}^{+}\right)$; HRFAB-MS $m / z$ 371.1278 [Calcd for $\mathrm{C}_{22} \mathrm{H}_{17} \mathrm{~N}_{3} \mathrm{O}_{3},\left(\mathrm{M}^{+}\right)$371.1270].

Compound 3: Brown amorphous powder; UV $\lambda_{\max }(\mathrm{MeOH}) 268(\varepsilon$ $29000)$ and 224 ( $\varepsilon$ 57000); IR (KBr) $v_{\max } 3410,1700,1520,1460$, and $1240 \mathrm{~cm}^{-1}$; ${ }^{1} \mathrm{H}$ - and ${ }^{13} \mathrm{C}-\mathrm{NMR}$ (Tables 1, 2); EI-MS $\mathrm{m} / z 399\left(\mathrm{M}^{+}\right.$); HR-FABMS $m / z$ 399.1184 [Calcd for $\mathrm{C}_{23} \mathrm{H}_{17} \mathrm{~N}_{3} \mathrm{O}_{4},\left(\mathrm{M}^{+}\right)$399.1219].

Compound 4: Pale yellow amorphous powder; UV $\lambda_{\max }(\mathrm{MeOH}) 268(\varepsilon$ 22000 ) and 225 ( $\varepsilon$ 38000); IR (film) $v_{\max } 3410,1690,1590,1460,1360$, and $1240 \mathrm{~cm}^{-1} ;{ }^{1} \mathrm{H}$ - and ${ }^{13} \mathrm{C}-\mathrm{NMR}$ (Tables 1, 2); EI-MS $m / z 415\left(\mathrm{M}^{+}\right)$; HR-FABMS $m / z 415.1179$ [Calcd for $\mathrm{C}_{23} \mathrm{H}_{17} \mathrm{~N}_{3} \mathrm{O}_{5},\left(\mathrm{M}^{+}\right)$415.1168].

Compound 5: Pale yellow amorphous powder; UV $\lambda_{\max }(\mathrm{MeOH}) 269(\varepsilon$ 20000) and 225 ( $\varepsilon$ 35000); IR (film) $v_{\max } 3410,1700,1460,1360$, and $1240 \mathrm{~cm}^{-1}$; ${ }^{1} \mathrm{H}$ - and ${ }^{13} \mathrm{C}-\mathrm{NMR}$ (Tables 1,2 ); EI-MS $\mathrm{m} / z 415\left(\mathrm{M}^{+}\right)$; HR-FABMS $m / z 415.1179$ [Calcd for $\mathrm{C}_{23} \mathrm{H}_{17} \mathrm{~N}_{3} \mathrm{O}_{5},\left(\mathrm{M}^{+}\right)$415.1168].

Cytotoxic Activity $\mathrm{HeLa}$ cells were seeded onto 96-well microtitre plates at $6 \times 10^{3}$ cells per well, and were pre-incubated for $24 \mathrm{~h}$ at $37^{\circ} \mathrm{C}$. The medium was replaced with fresh medium containing different concentrations of each isolated compounds. The cells were then incubated at $37^{\circ} \mathrm{C}$ for $24 \mathrm{~h}$. After the medium containing the isolated compounds was removed, cell pro- 
liferation was determined by fluorometric microculture cytotoxicity assay $(\text { FMCA })^{10)}$ using a fluorescence platereader. The ratio of the living cells was determined as the fluorescence in the sample wells expressed as a percentage of that in the control wells, and cytotoxic activity was indicated as an $\mathrm{IC}_{50}$ value.

VCR (vincristine) selected multidrug resistant variants of the human epidermoid carcinoma $\mathrm{KB}$ cells $(\mathrm{KB} / \mathrm{VJ}-300)^{11)}$ were a gift from Prof. M. Kuwano (Kyushu University School of Medicine). For the in vitro drug treatment experiments, KB cells, $1.1 \times 10^{4}$ cells $/ \mathrm{ml}$ of the cells were seeded in $195 \mu \mathrm{l}$ of culture medium/well in 96-well plates (Corning Glass Works), and incubated for $24 \mathrm{~h}$ at $37^{\circ} \mathrm{C}$ in a $5 \% \mathrm{CO}_{2}-95 \%$ air atmosphere. The cells were treated in triplicate with $5 \mu \mathrm{l}$ of graded concentrations of samples, and were then incubated in a $\mathrm{CO}_{2}$ incubator at $37^{\circ} \mathrm{C}$ for $72 \mathrm{~h}$. Cells viability was determined by the colorimetric assay using MTT. ${ }^{12)}$

Acknowledgments This work was partly supported by a Grant-in-Aid from the Ministry of Education, Culture, Sports, Science and Technology of Japan, by a Grant-in-Aid from the Fujisawa Foundation, and by a Grant-inAid from the Keimeikai Foundation.

\section{References}

1) Steglich W., Pure Appl. Chem., 61, 281-288 (1989).

2) Nakatani S., Yamamoto Y., Hayashi M., Komiyama K., Ishibashi M., Chem. Pharm. Bull., 52, 368-370 (2004).
3) Kamata K., Onuki H., Hirota H., Yamamoto Y., Hayashi M., Komiyama K., Sato M., Ishibashi M., Tetrahedron, 60, 9835-9839 (2004).

4) Nakatani S., Kamata K., Sato M., Onuki H., Hirota H., Matsumoto J., Ishibashi M., Tetrahedron Lett., 46, 267-271 (2005).

5) Steglich W., Steffan B., Kopanski L., Eckhardt G., Angew. Chem. Int. Ed. Engl., 19, 459— 460 (1980).

6) Fröde R., Hinze C., Josten I., Schmidt B., Steffan B., Steglich W., Tetrahedron Lett., 35, 1689-1690 (1994).

7) Hashimoto T., Yasuda A., Akazawa K., Takaoka S., Tori M., Asakawa Y., Tetrahedron Lett., 35, 2559-2560 (1994).

8) Yasuzawa T., Iida T., Yoshida M., Hirayama N., Takahashi M., Shirahata K., Sano H., J. Antibiot., 39, $1072-1078$ (1986).

9) Yamori T., Matsunaga A., Sato S., Yamazaki K., Komi A., Ishizu K., Mita I., Edatsugi H., Matsuba Y., Takezawa K., Nakanishi O., Kohno H., Nakajima Y., Komatsu H., Andoh T., Tsuruo T., Cancer Res., 59, 4042-4049 (1999).

10) Larsson R., Kristensen J., Sandberg C., Nygren P., Int. J. Cancer, 50, 177-185 (1992).

11) Hayashi M., Koike K., Rho M.-C., Kuwano M., Kishie T., Komiyama K., Anti-Cancer Drug Des., 16, 255-260 (2001).

12) Alley M. C., Scudiero D. A., Monks A., Hursey M. L., Czerwinski M. J., Fine D. L., Abbott B. J., Mayo J. G., Shoemaker R. H., Boyd M. R., Cancer Res., 48, 589-601 (1998). 